\title{
Stay Story
}

\section{Konstantin Ivanov*}

Department of Aerospace Control Systems, Almaty University of Power Engineering and Telecommunication, Kazakhstan

\section{Opinion}

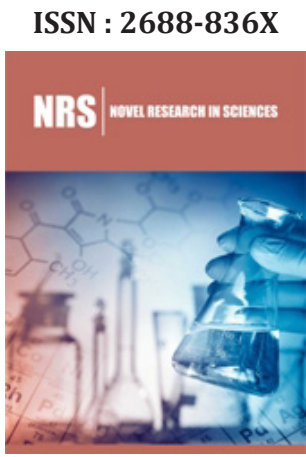

*Corresponding author: Konstantin Ivanov, Department of Aerospace Control Systems, Almaty University of Power Engineering and Telecommunication, Baitursinov Street, 126, Almaty, 050013, Kazakhstan

Submission: 漹 September 04, 2019

Published: 漹 September 30, 2019

Volume 2 - Issue2

How to cite this article: Konstantin Ivanov, Stay Story. Nov Res Sci.2(2). NRS.000533.2019.

DOI: 10.31031/NRS.2019.2.000533

Copyright@ Konstantin Ivanov, This article is distributed under the terms of the Creative Commons Attribution 4.0 International License, which permits unrestricted use and redistribution provided that the original author and source are credited.
Falling, falling, falling leaves

Well, let him, but the clear light,

In memory, in memory, in memory, in memory of a person,

Those who are not near to me.

The plane took off and powerful body shuddering, began to climb sharply. Last light failure, sinking of the heart and calm confidence of flight expanse concentrated silence ...

We Gena flying to open a new world to offer the largest companies (BMW, Volkswagen) my discovery, automatic transmission.

Gene - my graduate student, smart guy who will not miss her. It has inflated self-esteem, the desire to blame others for their troubles, lack of ethics.

Unexpected disruptions began to haunt us with the first steps. I calmly walked exit controls. Gena suddenly stuck. It turned out he had an exit visa by two days later.

I. This is your fault, - he told me. We were supposed to fly on the 7 th, and you have a ticket to the 5 th.

II. Yes, I'm with you on the phone for three days discussed the date of departure. How do I know that in your documents?

III. I just enraged this mess in the brain. Prior to that, he sent from Ust-Kamenogorsk to courier my invitation for visa, accompanied by an explanatory phrase, nothing. And then:

IV. - Well, you are all drawn up.

V. - Who and when?

VI. - You said yourself that $\$ 100$ for registration is not a problem.

VII. Even then I told him, overwrought by telephone that the information should be transmitted professionally. And now a new zamorochka.

VIII. When he took control, giving a bribe to fly to St. Petersburg, where we change, I shouted to him:

IX. This is your fault, you treat cases carelessly. This is a continuation of your shortcomings.

X. I understand everything perfectly.

XI. For the future, I sets out several times, the more so important. Your approach you will not fail again.

After landing in St. Petersburg, he threw himself from side to side, searching for a way 
how to proceed. After all, without a visa will not pass in Germany and will not take it. And all of these discussions with hints of my guilt.

I.

in fame!

Sit down and relax! And before that - or do put me

II. You need to take a box with the gearbox and fly on schedule. And I'll fly in a day.

III. But why should I pay for your sins? After all, besides the fact that I have to take responsibility for the goods that can not miss, bear the brunt, and I have yet to pay for extra weight!

He gave me the money, I took control and safely reached Munich. The language problem immediately stunned me. On the way out, I stood helplessly, unable to explain the customs officer that I need to meet (who and where it is not known). Finally I went out and when I saw the word «Shugaev». With some difficulty in English explained Christian Bock, sympathetic Germans from BMW that I came alone, and Shugaev be late.

He dragged his feet gave way to box up his car, and off we went. The bright sun was shining with the azure sky light clouds. Everything was pleasing to the eye with its purity and accuracy, was unusual and surprising. Conversations with Sideways was unfortunately brief. Meeting and discussion - the next day. One was a relief - it was contacted on the phone with Valera Berezkin and handed me a cell phone.

I. Where are you now? - I asked.

II. I'm going to France, I'm taking your current model, will meet tomorrow at the hotel.

I was so relieved. Valery will be able to translate, he was carrying a working model, then the discussion will be fine.

But what Gene! He forced me to take my box, even though he knew that he would mock. All wants to get their hands on. It is not the same to carry this weight back!

Bock brought me to the hotel «Bavaria», where, finally, I came to myself. In the evening, closer to the night, came Valera partner Bones. We discussed all the issues, prepared for the meeting. Morning arrived by car at the BMW Valeria (Bayern Werk motor). We met and performed in Boca cabinet. New joy - there is a translator from Russian into German. My report has turned out bright. The Germans (and Bok Foerster) not to show, but their issues, I felt interest. Of course, I explained to them all the subtleties of the opening, except for the parts needed for the practical implementation (know-how).

I. Will the layout work - I doubt it.

II. But he earned and brilliantly confirmed the scientific idea. The Germans were again asked questions, saying that they refuse to believe their eyes.

III. I have another project - I told them and showed the materials on the rotary - piston engine.

I opened a large assembly drawing shown pictures. But most importantly shows a layout showing the effect of creating two opposite combustion chambers when placing the crankshaft inside the piston. He spoke about the great prospects of the engine rotation speed increases due to the elimination of reciprocating inertial forces. This project is also interested in them.

I. Leave your materials, we consider them with specialists.

But I decided to focus only on the gearbox. And the engine and the electric motor to be adjusted and all the other projects left to themselves.

Pack more gear box did not even touch it. The effect was obvious. Bock, touched by the fact that I gave them souvenirs, coins with the portrait of Al - Farabi, and side - a jar of caviar, sent us an interpreter Smirnov and Foerster have lunch in the canteen. Smirnov, born in 1946 in Germany, was very excited about the opportunity to speak in Russian, and obviously we sympathized. Werner - a beautiful tall young fellow, PhD (by our standards - the candidate) was wholly directed to thinking of information received. His mind is working hard, refusing to accept the obvious. The same emotions going through me, when he created his theory. Only no one but God, it was explained to me that I am right. The very language of the theory of numbers and formulas to tell me:

I. It can not be otherwise! This has the effect of selfregulation. This power exists itself, it is not necessary to create, but it does not interfere with work.

II. Again, questions, questions ...

III. Torque output must be equal to the motor torque - Förster claimed.

IV. But you yourself have held and hindered the output shaft to a complete stop when the time is infinite.

V. So, too, the engine stopped.

VI. But then it will burn, because it is an ordinary nonregulated electric motor, and you have seen for yourself that it is rotated continuously, with constant torque.

VII. We went back to the side.

VIII. - The company will present you with the task of designing the structure. We hope to receive from you the solution in three months. You can then decide on further cooperation.

\section{And we parted.}

In the hotel we drove Anatoly Smirnov.

I. This is your great achievement - he said - that you could be interested in a world-renowned company, your happiness, your partners are energetic, ambitious and young. After all, the old officials do not need anything other than your own peace of mind.

II. And we did the right thing, did not reveal all the secrets? - Valery said. - After all, it causes mistrust.

III. You did the right thing by giving it myself the weight 
and solidity. Furthermore, one can not expect that the specific steps to conclude the contract will be reached immediately. it does not happen in business. The business idea should mature.

I settled for the hotel and at the insistence of genes for all the phone calls. After many delays, we boarded the metro (near the hotel), he drove me home, and then navigate to the station and tickets.

\section{And here I am in Stuttgart.}

I called the station.

I. Stand next to the platforms that will not waste responsible Minna. - I'll be right there.

II. Gentle breeze rustled her back unexpectedly.

III. Here I am!

She almost did not change. Only at the bottom of a light veil of eyes lay some sort of fatigue. Little - a little plumper. The voice of the young and sonorous. And all of it is flying, cheerful, prompt. Time left on my own trail. And she probably saw it, but she said that I'm the same as before. How times change. Previously, I took her to the car, and now she is on the luxurious «Audi», he sat me down in a comfortable seat, and the car expertly led by the mysterious streets of an unfamiliar city. Talk, talk ... Compliments, views and sadness on «She's not mine,» although otherwise it can not. And I have my own life. That house Minna - in the city center on a quiet street Landhauzshtrasse. We parked the car. The apartment is one bedroom, a lot of things, and this creates some confusion. We sit at the table, I, Minna and her friend Katya - a large woman, a Greek from it emanates warmth and simplicity. As in the old days, when the three of us with my wife Natasha sat up late into the night, drinking good wine and deliver each other elusive joy of communication.

Finally, I notice that I went for the second hour of the night. And we go to sleep. I was given a separate room.

In the morning, as usual, I woke up early. While everyone was asleep, I managed to record some important new solutions to scientific problems.

We had breakfast in a relaxed atmosphere with a sense of mutual sympathy among all participants. Today we go to the sauna with a mineral source - Minna said. - Remember, Kostya, what's there - all together and naked.

I once - heard that there were joint bath, but did not believe it. And it turns out - there is! Burning curiosity seized me.

Minna quickly our shells, explained the rules of conduct. And so the three of us, completely naked, only with towels, wander through the magnificent baths, swim in the pool with mineral water, which is then caresses, then beats elastic jets soared in the sauna and then a shower and pool, drink a nice mineral water sources. Around naked women, caught a very beautiful shape, pleasing to the eye and exciting the heart. But all seems natural and decent. And I stole a look at Minna, enjoying the sight of her naked figure, eyes caress her firmer breasts. I whisper to her

You have the most beautiful breasts ...It was a paradise on earth.

I went into the shower, threw off his armor disorder, relaxed, relaxed and fell asleep until morning.

Waking up very early, to please others comfort and thought that we should take advantage of enforced idleness. Firstly, it is necessary to shut down from all and just relax, and secondly, it is necessary to put in order my thoughts, to speculate about life in general, in the third, since I was in the beautiful country of Germany, why not become just a tourist, soak all new sensations. Thoughts flew one after another. I took a sheet of paper and began to write.

Here they are...

Mchishsya whole life at breakneck speed. «To have time to do everything!» But you have to stop, reflect on this life. Listen to yourself. Is it so important. What you want to strive for, what is despised, what is valuable, what's left? .

Perhaps the most important done. It made the discovery of two millennia. - Archimedes Lever got rid of fixed-point support.

Einstein created the theory of relativity. But to create a general field theory, he had not succeeded.

Maybe not worth it to me to strive for more? Stay. Although the prospects are enormous, but they only develop the discovery. You can spend time on other things. - Writing books and poems. Reflect life, to make sense of it. So much accumulated perceptions, makes now the credo and philosophy.

Minna - that it is in my life?

Minna - this is love in the past.

I used to love her. An impossible shade of sadness passed the love blew our meeting. She's not the kind of girl who could throw me on the neck with the idea «and nothing more is needed.» And I'm not the one. And now I have another love, another love. And my presence can create difficulties in her relationship with a man who is «younger than her twice.» And it is quite it is not necessary. I'd like to check out. And there was my meeting with her in Almaty. I would adjust to the meeting with Irochka, which is also «half younger than me.» And yet, and yet. In memory of our love, I probably would have gone to if it was she wanted. Indeed, so eager not only warmth, but it was love, her return, even if only briefly. Love - this is our life.

You can not step twice into the same river. - You're right, Minna, and this thought in my head. Still, it is possible if you want it. But what offense? No, we must take life for what it is. As an example, take offense at Claudia Schiffer (picture on the table) for the fact that she does not love me. Just sad, sad ... People! Love each other.

Well. Ahead forced Week carefree life. I spend it on the alignment of values, making sense of life, aspirations analysis, assessment of the relationship with the world, with women more likely. Relationships with loved ones. And I drink cheap but delicious Portuguese wine, whole body feel a lack of time and 
reflect on life. Natasha! Still, I am being unfair to you. Let all my life you've been careless, never took care of me (the food - it's for two people), demanded money. But you I gave birth to daughters. Three daughters from me. Zhenya, Tanya, Lena. I love them equally, and I want the material they received from me equally. I forgive you, Natasha, your inconsistency my desires and aspirations. But we had love. And I made that will never forget. I'm sorry, I'm too dry treated you in the past few years. Sorry...

Noisy heater. Driving thought ...

Only half past five in the evening and already dark. Northern latitudes. I just woke up. So I sleep well. Under a curtain I had a dream! «We arrived at the Mine elevator to some fifth floor. children a feeling about us. Parting. Minna kisses me, again and again. I look at her in surprise.

This is because you - good. «

How little we need to be happy! We are so used mostly content with little. All life. Maybe enough ?! And because I think I deserve more. One serious intent there: if I make a lot of money (millions), I'll create a «World Inventive Center». It will provide support to all the inventors of the world. How hard is it to bring the greatest discovery to the world community! A simple invention? It is necessary to remove the brake with scientific progress. I walked calmly through the city, seeing the surrounding unusual world and philosophizing.

Then I decided to call Minna, remembering his phone card. But however much I tried, I could not. And suddenly it dawned on me - you must first lift the handset and then dial the number! And it worked out.

I. Minna! I'm in Hanover, at the hotel.

II. And I was going through, where have you gone. Do not call. How are you?

III. We engage with Volkswagen. But now there is nothing to do. I rest.

IV. Katya also entertained.

V. Give her a verse of the song, I did not finish:

«I swear that I will be cleaner and kinder

And I do not throw each other ever in trouble,

I hear a voice, and I hasten to the call soon

On the road, on which there is no trace of «...

These words are to some extent reflected the bitterness of my reflections. Minna recorded.

Maybe not see each other again, I congratulate you happy birthday! Until...

I tried to call his brother Victor in Saint - Petersburg, but probably not the one dialed area code. The next day was Sunday. I wandered into the church, I was given a book, and the first time I was at a church service. Spiritual food is needed, probably a man.
But it is not enough time for everything. Katya convinces me that God helps me, and I should be grateful to him. So I was in the church.

Let's go to me - Minna said.

Realizing that her hesitate, we still got in the car.

Gene, so is not accepted to do business, - said Minna. - you are imposing some unimaginable rules. Should have specific names, phone numbers, dates. You deprive people of highly paid time, unable to provide them with specific information.

But still, we have to ... etc - the usual verbal diarrhea genes.

Enough! - I exploded. - I went on about you, Gene. So the more this will never happen. We can not lose the face of the company. I will not participate more in those of your adventures. Now I will decide what to do.

Calm down, Kostya! - Minna touched my arm.

I am uncomfortable, I feel free again, you - I said.

You know, I have learned to say «no» in their life, when it is needed. And it was very difficult. So now I do not you just say «no.» But if I say «yes», then it is too hard. Everything is good.

I'm back in the familiar apartment. Minna fed us. We discussed the situation with the affairs of our company. Gene lights up the idea of cooperation with us Minna. It turned out that we have a great opportunity that she knows the business world, the rules of the game, has access to the Internet. She led us to the computer. Gene Give me your data by Daimler - Chrysler (firm, jointly with Mercedes).

Through the Internet, she immediately found the addresses, names, phone numbers.

And now there is a conversation on the phone with a specific person. Minna diplomacy prevails, and it takes us an answer.

i. Well, I agree to personally look at your materials and give a concrete answer to the company «GT». Send them to my address.

ii. It is necessary to prepare the accompanying text, otkserit materials and send them - Minna said.

iii. We were shocked to Gena operational issues and the ability to settle the case Minna.

iv. It was too late. Minna us a bed bed, and we went to bed.

v. Minna - an indispensable employee - Gene said. - Be sure to persuade her to go to Opel.

vi. Finally, we overhauled rest and catch up on sleep after a long ordeal.

vii. Minna morning, I set the table and put a bottle of champagne.

viii. But we do not drink in the morning - we began to argue.

ix. No, let's have a drink.

x. Behind our success ... - I began, and then realized to my 
shame that because today's her birthday!

xi. What I'm talking about?! - I began to mend. - Minna, I congratulate you happy birthday! You're always in my heart. We love you very much.

xii. Minna! I am very glad to meet you, God sent you to us. I ask you and I hope for your agreement to cooperate with us. enthusiastically said Gene.

xiii. We discussed the situation. Minna has agreed to help us, to participate in the affairs of the company, go to Opel.

xiv. Kostya! I remember you eight years ago sent a letter with the request to helpyou with the engine. But then the correspondence stopped.

xv. Yes, the way that I was, I would not have given such results. Only access to the London-based firm is now helping to negotiate with the Western world.

xvi. Then we went to Minna in some office, otkserit materials. Minna printed prepared me a brief description and cover letter. All sealed in an envelope and mailed in Daimler - Chrysler.

xvii. Today is my birthday - Minna said. - my friends come. I need to prepare. I'm probably going to be busy in the evening. I'll try to find you a room for one night. But you still give me a call at $5 \mathrm{pm}$. Maybe the situation will change.

We thanked Minna and went to the city with the area Ostendplatts to which Minna took us. On the route, which she has set us, we are lost, and the long way still got to the station, constantly bickering with each other on the road. On the way to the supermarket bought a beer, sausages and bread.

It is located at the train station and enjoy lunch. Then we went on from the Königstraße Station to see the city. We have been looking for a gift Minna - four-volume Heine, to which it drew attention in my first visit. Finally, we find a store that will send it by post parcel.

\section{At 5:00 a call from the station.}

i. Come to me - Minna said. - Celebrate the birthday and stay with me.

ii. And we rushed to Minna, quickly finding the way from the station to her street, but still gave then hook.

iii. We met her on the street.

iv. She led us into the house.

v. They drank wine and brandy. Appetizer was a dream gourmet. Huge baked juicy piece of meat. There were guests, but then left. We stayed three.

vi. Minna, you are my inspiration, a part of my soul! You tangible vision of my past. I wish you love and eternal youth!

vii. Gene also spoke compliments, penetrating her increasing affection.

viii. You know how many events flown in the past ten years, you left. There was a moment when you can be saved me from the abyss, on the brink of which I was. I then wrote the story. There were the following lines: «The Rumble landslide broke a phone call in the night.» This is your call was a straw to a drowning man.

ix. Send me this story. Really we have such a situation ?!

What happened, it happened ...

But late in the midnight hours.

We remove from the table in a hurry and go to bed, turn on the alarm.

I woke up in a loss to explain why so early alarm goes off: But the clock was all right.

Minna had to wake up.

The first tram was driving on the morning town us to the station. It was a strange company: a lady with a dog and two rabbits (who do not have tickets). Dog suddenly appeared. Minna was sorry to leave her home and took her, seated in a large bag.

With the transfer quickly got to the station, we got tickets and quickly got to Rüsselsheim.

On the eve of discussing with the ticket problem, I got back into some kind of semantic impasse situation with Gena.

i. If Minna would not go, and we'll take a ticket in advance, whether we pass it? - I asked.

ii. In response, he rushed insurmountable absurdity:

iii. Oh, she would not go. So now we will urgently seek a translator! So would immediately and said. I did not know that she is optional!

iv. You're there in his mind? Russian language you understand or not? You yourself talking to her! What a suspicion! Answer the spoken rather than think through twisted imagination! You can return the ticket, or not ?! - was the question.

Needless to say, he gets me with their complexes ...

The Rüsselsheim company lady with a dog and rabbits continued on the bus to Bischofsheim.

Prior to this, the town wall stood Opel housing. «Maybe there and we had to go» - we were lost in conjectures. The bus was driving through the city. We stowaways, relieved jumped at the last stop and on the advice of the driver ran to the phone - machine. It turned out that we got right. But we still had a way to four kilometers. I was ashamed to admit on the phone that we are not in a car, and we wandered around the track. We reached finally to some store, where we had an appointment, albeit with a delay of 15 minutes. Minna again calling on the phone. Half an hour later there was a young guy and took us to the storage building of the plant, taking the bag of dog Minna.

We are located in a large conference room on the opposite side of the negotiating table. After a brief introduction about our genes an Internet search of contacts with the company I started my report. 
Minna successfully translated.

In dvuhpodvizhnom mechanism does not apply the law of statics. - everyone smiled with understanding, both in the form of a jester in the circus.

However, there is a law of mechanics, the application of which is necessary and sufficient! - It's the law Kinetostatics - the amount of work is equal to zero. This forms the basis of our scientific discovery of the property of self-regulation mechanisms dvuhpodvizhnyh.

All the questions I answered quickly, professionally and with authority, showing new technical solutions, drawing new schemes.

Smile disappeared partners when they turn their hands tested layout work that Gene almost ditched, interrupting pathetic bundles of wires. I revived him by a thread.

Again Gene tried to drive his horse into a gallop, although it was clear that the instant decision to cooperate is not. Partner must mature!

We have promised to consider the information and to communicate its decision. Conducted on the factory bus and then walk almost to the station.

i. Ivanov - the responsibility of scientists, - the path urged Minna. - He would never have dared to present unproven scientific and technical ideas.

ii. On the train we got to Frankfurtta, and then our paths diverged.

We put Minna on the express train to Stuttgart. Here she is sitting at the window of the train now, he will begin to move, and will completely disappear, be dissolved in the river of time, this fleeting life episode, stirred up memories of the past.

\section{iii. Farewell, Minna!}

On the way home, Jack briefed on the situation in Almaty, I told him - about his trip.

We arrived at my office on Isaev (not to go the same night as much in Aksai), and buried her in a locked door. The castle was sticking a piece of the key.

Jack opened the door with the help of a screwdriver.

Everything!!! I'm at home.

\section{Epilogue}

We made our way!

But the expectation of a miracle better than the miracle . 